World Archaeological Congress

\section{South African exclusion causes academic schism}

REPORTS to the contrary notwithstanding, the World Archaeological Congress will take place this September in Southampton, England, without the participation of South A frican and Namibian scientists, but it will not enjoy the blessing of the International Union of Prehistoric and Protohistoric Sciences (IUPPS), which will instead recognize a congress at Mainz, West Germany, as its official quinquennial meeting.

At a meeting of the British executive committee for the Southampton congress at the British Museum, organizing secretary Professor Peter Ucko said plans for the congress will go ahead. But three of the five members of the executive committee, Sir David Wilson, Professor Leslie Alcock and Professor Colin Renfrew, resigned, saying they could no longer officially support the Southampton congress.

IUPPS had threatened to withdraw its support for the meeting unless the British organizers lifted their ban on South African and Namibian participation. After a meeting in Paris last month, the executive committee of IUPPS gave the British organizers until 15 February to reinvite the South Africans. The executive committee also insisted on written guarantees that groups opposing South African particiaption would not disrupt the congress.

For the past three weeks, organizers of the Southampton congress have been trying to work out a formula that would allow them to comply with the IUPPS demands. One compromise proposal would have been to seek approval of South African participation from the groups opposing it on a one-time-only basis. Once the Southampton congress received IUPPS approval, a motion would be put forward to ban South African scientists from any future meeting until South Africa's apartheid policy was lifted. But in the end, this compromise fell through, and Ucko was forced to acknowledge the he could not meet the IUPPS requirements.

According to Professor John Evans, the issue of South African participation might never have come up but for the attempts by meeting organizers to broaden the focus of the Southampton meeting. The last IUPPS international meeting was held in Mexico, the first time ever outside Europe, but hopes for a truly international meeting at that time were not realized. In trying to attract wider participation by nations outside the industrialized West, the issue of South African participation was thrown into stark relief.

Evans resigned last month as president of the executive committee of IUPPS and the British executive committee because he too did not want to be associated with a congress held without IUPPS endorsement (see Nature 319, 251; 1986).

The Southampton meeting organizers now find themselves in an extremely difficult position. Encouraged initially by IUPPS to provide a broader scope to the Southampton congress by doing more to encourage participation of developing countries, they saw banning South African scientists as their only alternative. But having succeeded in attracting some formerly neglected parts of the world archaeological community, they now find they have alienated many mainstream archaeologists. Ucko estimates that the Southampton congress will attract only 1,000 of the $3,000-4,000$ scientist who might otherwise have attended if IUPPS support had not been withdrawn.

Ucko maintains that the IUPPS execu-

\section{Washington}

THE National Institutes of Health (NIH) are getting tough about enforcing animal welfare rules. NIH's Office for Protection from Research Risks has started making unannounced visits to check conditions in animal laboratories using Public Health Service funds, and as a result has suspended NIH funds to the Health Sciences Division of Columbia University in New York.

The order against Columbia was made by NIH director James Wyngaarden after he received an interim report from a team that visited Columbia's Health Sciences Division on 23 and 24 January. The report identified deficiencies in four areas: veterinary care, sterility of areas where animals recuperate from surgery, housing of dogs under quarantine and methods of reducing health risks to personnel. The suspension affected only NIH funds used for research on vertebrates other than rodents, but the university has voluntarily halted all other research until the facilities are improved.

The new get-tough policy at NIH came into force formally at the end of last year, when the Public Health Service introduced new regulations that significantly tighten the requirements on grantee institutions that conduct animal research. Many of what were previously suggestions relating to animal use committees became tive committee has exacerbated the situation. At its January meeting in Paris, the committee refused to consider the positions of members from developing countries who could not be present. Ucko considers their actions "utterly scandalous", claiming the committee was only too happy to move the congress to Mainz in order to maintain the stranglehold of Western European scientists on the world archaeological community.

Opponents of the South African ban say it is an issue of academic freedom. They maintain that no bona fide scientist should be excluded from participating in a scientific congress for political reasons. Nobody can oppose the concept of academic freedom, says Professor Colin Renfrew, but blindly adhering to it is pointless if it causes de facto discrimination. In this case, including South Africans would mean not including Indians and Nigerians, among others, who have said they will not attend if the South Africans do. "I see no solution to this dilemma", says Renfrew.

There is no question that the issue of the Southampton congress has caused a split in the archaeological community. Says John Evans, "a certain amount of damage has been done, and it will take time to repair it".

Joseph Palca

\title{
Tip-off leads to NIH ban
}

mandatory requirements: a non-scientist must be included, and the committee must review all research proposals involving animals, to name but two. In addition, institutions were required to submit reports to NIH detailing their arrangements for meeting the new regulations. Columbia University submitted its report well before the 31 December deadline and made its failings plain, although the university had as long as a year ago been aware that "considerable improvements" were necessary and had instituted a longrange plan to achieve them. NIH were tipped off to investigate Columbia by an animal welfare group, and will be ready to listen to similar tip-offs in future.

The research that is now on hold at Columbia involves rabbits, dogs, sheep and primates. Research topics include cardiovascular disease, fertility, fetal development, immunology, birth defects (including Down's syndrome), and arthritis.

Other unannounced inspections can be expected, and NIH is not being shy about enforcing its conditions. NIH funds to the City of Hope Medical Center in Duarte, California have been suspended, and the University of Pennsylvania is barred from new NIH research funds pending agreement over requirements; head injury research at the university was suspended indefinitely last summer following discovery of serious abuses.

Tim Beardsley 